\title{
Combined use of vasopressin and synthetic hypothalamic releasing factors as a new test of anterior pituitary function
}

\author{
L M SANDLER, J M BURRIN, G F JOPLIN, S R BLOOM
}

\begin{abstract}
Nine normal volunteers and 15 patients with pituitary disorders were given a combined test of anterior pituitary function using four hypothalamic releasing factors and arginine vasopressin. Rapid sequential intravenous infusions of human corticotrophin releasing factor $100 \mu \mathrm{g}$, growth hormone releasing factor $100 \mu \mathrm{g}$, luteinising hormone releasing hormone $100 \mu \mathrm{g}$, and thyrotrophin releasing hormone $200 \mu \mathrm{g}$ were administered. Arginine vasopressin (10 pressor units) was given intramuscularly at the same time. Plasma or serum samples were assayed for concentrations of cortisol, growth hormone, luteinising hormone, follicle stimulating hormone, prolactin, and thyroid stimulating hormone at multiple times for 120 minutes. No troublesome side effects occurred. The results of the releasing factor combined test with arginine vasopressin were compared in the same subjects with a conventional combined test using insulin together with thyrotrophin releasing hormone and luteinising hormone releasing hormone. No difference was observed in the basal and peak concentrations of luteinising hormone, follicle stimulating hormone, thyroid stimulating hormone, and prolactin. Both cortisol and growth hormone responses to the releasing factors with arginine vasopressin were much greater than those seen with insulin induced hypoglycaemia or the combined releasing factors without arginine vasopressin. Patients with pituitary hypofunction were similarly recognised in both studies. There was a rapid increase in all hormone values with a peak usually by 60 minutes.

In most people adequate assessment of individual hormone reserves may be achieved using basal, 30 minute, and 60 minute samples. This new combined releasing factor test appears to be a safe, rapid, and useful test of anterior pituitary function.
\end{abstract}

\footnotetext{
Department of Medicine, Royal Postgraduate Medical School, Hammersmith Hospital, London W12 OHS

L M SANDLER, MB, MRCP, senior registrar

J M BURRIN, BSC, PHD, principal biochemist

G F JOPLIN, PHD, FRCP, professor

S R BLOOM, MD, FRCP, professor

Correspondence and requests for reprints to: Professor Bloom.
}

\section{Introduction}

Several stressful stimuli have been used to assess pituitary growth hormone and adrenocorticotrophic hormone reserves, of which insulin induced hypoglycaemia is the most widely used. Implicit in the induction of hypoglycaemia is the necessity for continuous and close medical supervision. Furthermore, this test very often causes unpleasant effects. The test is also reported to give variable growth hormone responses under similar conditions.

Over the past two decades hypothalamic factors have been described which selectively stimulate specific cell types of the adenohypophysis. The isolation and characterisation of thyrotrophin releasing hormone ${ }^{2}$ and luteinising hormone releasing hormone ${ }^{3}$ led to extensive clinical use of these factors combined with insulin hypoglycaemia as a combined test of anterior pituitary function. ${ }^{4}$ Two further hypothalamic peptides have now been characterised and synthesised: growth hormone releasing factor ${ }^{5}$ and corticotrophin releasing factor. ${ }^{6}$

Growth hormone releasing factor selectively stimulates the release of growth hormone in $\operatorname{man}^{7}$ and has been used in clinical studies in adults ${ }^{89}$ and children. ${ }^{111}$ Corticotrophin releasing factor is effective in rat pituitary in stimulating release of adrenocorticotrophic hormone both in vitro ${ }^{12}$ and in vivo. ${ }^{13}$ Corticotrophin releasing factor also releases adrenocorticotrophic hormone with consequent increases in plasma cortisol in man, ${ }^{1416}$ though it is generally thought to be less effective than insulin hypoglycaemia. ${ }^{17}$ In normal men the coadministration of the four release factors thyrotrophin releasing hormone, luteinising hormone releasing hormone, corticotrophin releasing factor, and growth hormone releasing factor results in increments in the plasma concentrations of their target anterior pituitary hormones indistinguishable from those seen after seperate administration. ${ }^{18}$ Vasopressin is a potent stimulator of the secretion of adrenocorticotrophic hormone in isolated rat pituitaries ${ }^{19}$ and in human pituitary tumour cells. ${ }^{1720}$ Both studies showed strong synergistic stimulation of adrenocorticotrophic hormone secretion by ovine corticotrophin releasing factor and synthetic vasopressin.

We report the combined use of the four releasing factors together with vasopressin as a combined test of anterior pituitary function (the releasing factor test) in normal volunteers and patients with pituitary disorders. The results were compared with those of the conventional combined test using insulin (the insulin combined test). 


\section{Materials and methods}

Synthetic luteinising hormone releasing hormone was purchased from Ayerst Laboratories, thyrotrophin releasing hormone from Roche Products Ltd, and arginine vasopressin from Parke-Davis (Pitressin). Soluble insulin was used in the insulin combined test.

Growth hormone releasing factor (1-29 amide) and human corticotrophin releasing factor were obtained from Bachem Laboratories, Torrance, USA. Each peptide was dissolved in sterile hydrochloric acid $(1 \mathrm{nmol} / 1 ; 3 \cdot 6 \mathrm{ng} / 100$ $\mathrm{ml}$ ) and sodium chloride (154 nmol/1;9.0 ng/ml) containing $0.25 \%$ human serum albumin. The solution was sterilised by Millipore filtration and shown

TABLE I-Clinical effects of combined pituitary function tests

\begin{tabular}{lcccccc}
\hline & Nausea & $\begin{array}{c}\text { Mood } \\
\text { change }\end{array}$ & Sweating & Pallor & Flushing Palpitation \\
\hline $\begin{array}{c}\text { Insulin combined } \\
\text { test }(\mathrm{n}=23)\end{array}$ & 16 & 18 & 23 & 21 & 0 & 21 \\
$\begin{array}{c}\text { Releasing factor } \\
\text { test }(\mathrm{n}=24)\end{array}$ & 15 & 8 & 2 & 0 & 18 & 5 \\
\hline
\end{tabular}

of the mean (SEM), except where mentioned otherwise. The Mann-Whitnew test was used to evaluate statistical significance when comparing the result $\mathbf{S}$ for the two protocols.

\section{Results}

Clinical effects-Table I summarises the observed effects of both the insulin combined test and the releasing factor test. No changes occurred im blood pressure or temperature after administration of the releasing factors? An increase in pulse rate of $5-10$ beats/min and lasting up to 30 minutes wa@ noted in most subjects undergoing the insulin combined test. With the: releasing factor test transient nausea, flushing, and a feeling of warmth ove the face and upper trunk occurred. Neither symptom persisted for more than 10 minutes in any subject and was in no case described as unpleasant The mean nadir blood glucose value during the insulin combined test was $1.8 \mathrm{mmol} / \mathrm{l}(32.4 \mathrm{mg} / 100 \mathrm{ml}$; range $1 \cdot 6-2 \cdot 2 \mathrm{mmol} / \mathrm{l}(28 \cdot 8-39 \cdot 6 \mathrm{mg} / 100 \mathrm{ml}) \stackrel{\text { 吊 }}{\text { (1) }}$ which was enough to produce symptoms in all subjects.

Luteinising hormone, follicle stimulating hormone, thyroid stimulating hormone, and prolactin-There was no significant difference in the response of any of these hormones to either the insulin combined test or the releasing factor test in the patients with pituitary disease. Table II gives the results for

TABLE II-Hormone results in normal subjects during insulin combined test and releasing factor test ( $n=9$ for both tests). Results expressed as mean (SEM) [range]

\begin{tabular}{|c|c|c|c|c|}
\hline & \multicolumn{2}{|c|}{ Basal } & \multicolumn{2}{|c|}{ Peak } \\
\hline & Insulin combined test & Releasing factor test & Insulin combined test & Releasing factor test \\
\hline $\begin{array}{l}\text { Luteinising hormone (U/l) } \\
\text { Follicle stimulating }\end{array}$ & $4.5(0.4)[2 \cdot 7-6 \cdot 5]$ & $3 \cdot 8(0 \cdot 7)[2 \cdot 2-8 \cdot 2]$ & $27 \cdot 0(5 \cdot 1)[11-50]$ & $23 \cdot 6(5 \cdot 1)[5 \cdot 4-50 \cdot 0]$ \\
\hline $\begin{array}{l}\text { hormone (U/1) } \\
\text { Thyroid stimulating }\end{array}$ & $2 \cdot 7(0 \cdot 4)[1 \cdot 0-4 \cdot 3]$ & $2 \cdot 4(0 \cdot 4)[1 \cdot 0-4 \cdot 5]$ & $6 \cdot 2(1 \cdot 2)[1 \cdot 6-13 \cdot 7]$ & $6 \cdot 3(1 \cdot 3)[1 \cdot 7-17 \cdot 9]$ \\
\hline $\begin{array}{l}\text { hormone }(\mathrm{mU} / \mathrm{l}) \\
\text { Prolactin }(\mu \mathrm{g} / \mathrm{l}) \\
\text { Cortisol }(\mathrm{nmol} / \mathrm{l}) \\
\text { Growth hormone (mU/l) }\end{array}$ & $\begin{array}{c}<1 \cdot 0[\text { all }<1 \cdot 0] \\
13 \cdot 2(2 \cdot 8)[8 \cdot 8-29 \cdot 0] \\
501(46)[312-669] \\
5 \cdot 8(1 \cdot 4)[<1 \cdot 0-11 \cdot 4]\end{array}$ & $\begin{array}{c}<1 \cdot 0[<1 \cdot 0-1 \cdot 4] \\
11.0(2 \cdot 8)[6 \cdot 7-28 \cdot 0] \\
332(50)[93-619] \\
6 \cdot 7(1 \cdot 8)[1 \cdot 1-22 \cdot 0]\end{array}$ & $\begin{array}{l}10 \cdot 2(2 \cdot 4)[2 \cdot 1-25 \cdot 0] \\
62 \cdot 2(8 \cdot 8)[31-81] \\
674(42)[460-785] \\
31 \cdot 6(8 \cdot 8)[16-77]\end{array}$ & $\begin{array}{c}14 \cdot 0(2 \cdot 8)[3 \cdot 1-26 \cdot 3] \\
58 \cdot 8(9 \cdot 8)[32-59] \\
740(50)[569-1180] \\
47 \cdot 8(9 \cdot 1)^{\star}[8 \cdot 1-141 \cdot 0]\end{array}$ \\
\hline
\end{tabular}

by the limulus test to be non-pyrogenic. It was lyophilised under vacuum and stored in $100 \mu \mathrm{g}$ aliquots at $-20^{\circ} \mathrm{C}$. Immediately before use each phial was brought to room temperature and made up for injection with sodium chloride $(154 \mathrm{nmol} / \mathrm{l})$ and hydrochloric acid $(1 \mathrm{nmol} / \mathrm{l})$.

Protocol-An intravenous cannula was inserted 30 minutes before the start of each study at 0800 . The insulin combined test consisted of consecutive intravenous injections over two minutes of luteinising hormone releasing hormone $(100 \mu \mathrm{g})$, thyrotrophin releasing hormone $(200 \mu \mathrm{g})$, and soluble insulin $(0 \cdot 15 \mathrm{U} / \mathrm{kg})$. The releasing factor test consisted of consecutive intravenous injections over two minutes of growth hormone releasing factor $(100 \mu \mathrm{g})$, human corticotrophin releasing factor $(100 \mu \mathrm{g})$, luteinising hormone releasing hormone $(100 \mu \mathrm{g})$, and thyrotrophin releasing hormone $(200 \mu \mathrm{g})$. An intramuscular injection of arginine vasopressin (10 pressor units) was also given at time zero. For both tests blood was drawn at -30 , zero, 30, 60, 90, and 120 minutes. In nine subjects, including four normal volunteers, an identical study was undertaken using the four releasing factors but omitting vasopressin. Concentrations of growth hormone, luteinising hormone, follicle stimulating hormone, thyroid stimulating hormone, and prolactin were measured by double antibody radioimmunoassay. ${ }^{21}$ Cortisol was measured by a solid phase first antibody radioimmunoassay. ${ }^{22}$

Subjects-Nine normal volunteers (six women) aged 22-28 years (mean 24) underwent both the insulin combined test and the releasing factor test in random order. In four women the releasing factor test was undertaken in the early follicular phase and in two in the mid-luteal phase. The insulin combined test was carried out within a few days before or after the releasing factor test. Fifteen patients aged 25-27 years (mean 36) were similarly studied with both tests: five had prolactinomas (two untreated, two in whom bromocriptine was stopped six weeks before the study, one given interstitial radiation); five acromegaly (two active, one posthypophysectomy, one given interstitial radiation, one given external irradiation); one Cushing's syndrome due to ectopic secretion of adrenocorticotrophic hormone; two non-functioning tumours; and two idiopathic isolated diabetes insipidus. No patient was having cortisone replacement therapy, but two were receiving thryoxine, one testosterone, and one oestrogen replacement therapy. All subjects fasted overnight and gave informed consent to the procedures.

Statistical methods-Values are presented as the mean and standard error

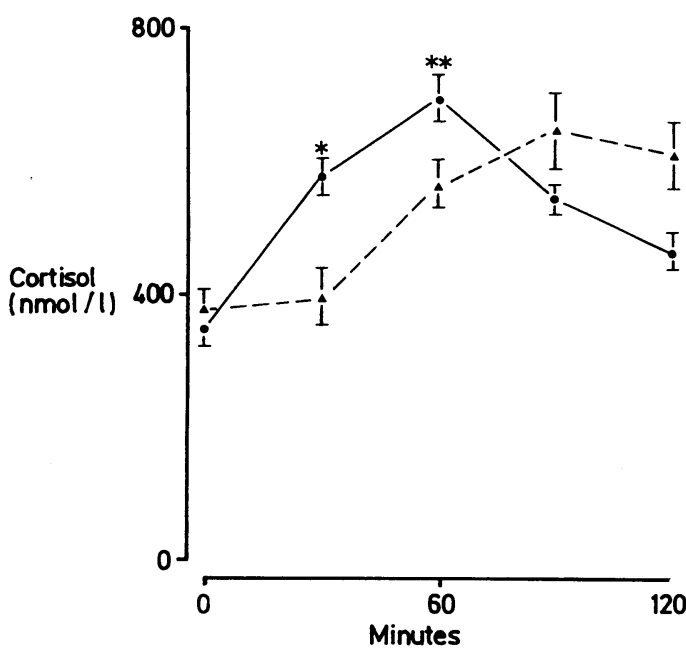

FIG 1-Comparison of plasma cortisol response to releasing factor test $(\boldsymbol{O})$ and insulin combined test $(\Delta)$ in 14 patients with pituitary disorders. Points are means. Bars are SEM. ${ }^{\star} \mathrm{p}<0.02$, ${ }_{\star \star \star} \mathrm{p}<0 \cdot 01$.

Conversion: $S I$ to traditional units-Cortisol: $1 \mathrm{nmol} / \mathrm{l} \approx$ $0.036 \mu \mathrm{g} / 100 \mathrm{ml}$.

normal volunteers. In these also there was no significant difference in the hormonal response between the two tests.

Cortisol-Figure 1 shows the changes in plasma cortisol values after夰 both combined pituitary function tests in all patients except the one with Cushing's syndrome. The single patient with a history of external irradiation to the pituitary gland showed a considerably greater peak concentration $(833 \mathrm{nmol} / \mathrm{l} ; 30 \mu \mathrm{g} / 100 \mathrm{ml})$ in the releasing factor test than in the insulin combined test $(360 \mathrm{nmol} / 1 ; 13 \mu \mathrm{g} / 100 \mathrm{ml})$. For all subjects combined the mean basal concentration was 346 (SEM 32) nmol/1 (12.5 (1.2) 
$\mu \mathrm{g} / 100 \mathrm{ml}$ ) before the releasing factor test rising to a mean peak of $719(40)$ $\mathrm{nmol} / 1(26.0(1 \cdot 4) \mu \mathrm{g} / 100 \mathrm{ml})$ at 60 minutes, and $404(33) \mathrm{nmol} / 1(14 \cdot 6(1 \cdot 2)$ $\mu \mathrm{g} / 100 \mathrm{ml})$ before the insulin combined test rising to $604(58) \mathrm{nmol} / \mathrm{l}(21 \cdot 9$ $(2 \cdot 1) \mu \mathrm{g} / 100 \mathrm{ml})$ at 90 minutes $(\mathrm{p}<0 \cdot 001)$. The mean maximal increment from basal was thus greater with the releasing factor test $(373(19) \mathrm{nmol} / \mathrm{l}$;

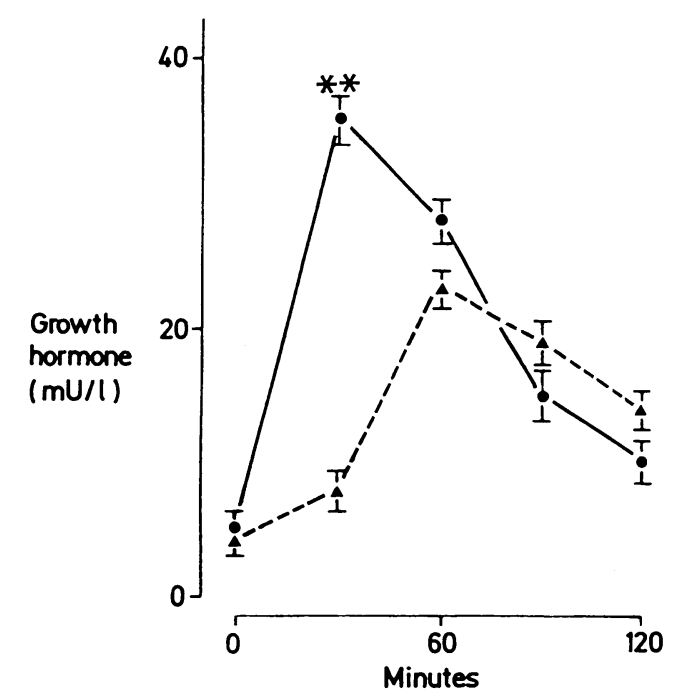

FIG 2-Comparison of serum growth hormone response to releasing factor test $(\boldsymbol{O})$ and insulin combined test $(\boldsymbol{\Delta})$ in 13 patients with pituitary disorders. Points are means. Bars are SEM. ${ }^{\star \star} \mathrm{p}<0.01$

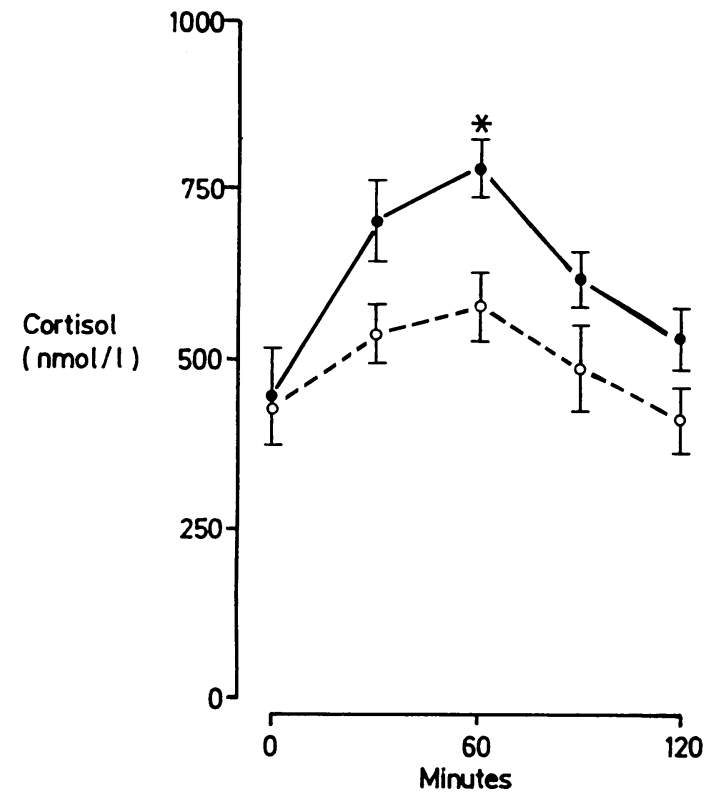

FIG 3-Comparison of plasma cortisol response to combined releasing factors with $(O)$ and without $(\bigcirc)$ arginine vasopressin in nine subjects. Points are means. Bars SEM. ${ }^{\star} \mathrm{p}<0 \cdot 05$.

Conversion: SI to traditional units-Cortisol: $1 \mathrm{nmol} / \mathrm{l} \approx$ $0.036 \mu \mathrm{g} / 100 \mathrm{ml}$.

$13.5(0 \cdot 7) \mu \mathrm{g} / 100 \mathrm{ml})$ than with the insulin combined test $(200(11) \mathrm{nmol} / \mathrm{l}$; $7 \cdot 2(0.4) \mu \mathrm{g} / 100 \mathrm{ml})(\mathrm{p}<0.01)$. In the nine normal volunteers the mean cortisol increment from basal was $408 \mathrm{nmol} / \mathrm{l}(14 \cdot 8 \mu \mathrm{g} / 100 \mathrm{ml}$; range 104$705 \mathrm{nmol} / \mathrm{l}(3 \cdot 8-25 \cdot 5 \mu \mathrm{g} / 100 \mathrm{ml}))$ during the releasing factor test and 173 $\mathrm{nmol} / \mathrm{l}(6 \cdot 3 \mu \mathrm{g} / 100 \mathrm{ml}$; range $135-444 \mathrm{nmol} / 1(4 \cdot 9-16 \cdot 1 \mu \mathrm{g} / 100 \mathrm{ml}))$ after the insulin combined test $(\mathrm{p}<0.01)$ (table II).

Growth hormone-The growth hormone response to the two combined pituitary function tests in the patients was compared (fig 2) after excluding two patients with high circulating concentrations of growth hormone due to active acromegaly. Basal growth hormone concentrations were similar in the two tests but the peak concentrations achieved were very different. The releasing factor test produced a peak of 35.7 (SEM 3.6) $\mathrm{mU} / \mathrm{l}$ at 30 minutes compared with a peak of $22 \cdot 0(3 \cdot 6) \mathrm{mU} / \mathrm{l}$ with the insulin combined test at 60 minutes $(\mathrm{p}<0.01)$. A greater growth hormone response to the releasing factor test was also seen in the nine normal subjects (table II)

Releasing factor test without vasopressin-The releasing factor test was repeated in nine subjects with the omission of arginine vasopressin. No person noted any difference in symptoms between the two tests. There was no significant difference between the basal and stimulated concentrations of luteinising hormone, follicle stimulating hormone, thyroid stimulating hormone, and prolactin. The cortisol and growth hormone responses, however, were significantly greater when the releasing factors were given with arginine vasopressin. With vasopressin cortisol rose from a basal concentration of $440(\mathrm{SEM} 57) \mathrm{nmol} / \mathrm{l}(15 \cdot 9(2 \cdot 1) \mu \mathrm{g} / 100 \mathrm{ml})$ to a peak of 776 (45) $\mathrm{nmol} / \mathrm{l}(28 \cdot 1(1 \cdot 6) \mu \mathrm{g} / 100 \mathrm{ml})$ at 60 minutes, and without vasopressin from $428(43)$ to $575(40) \mathrm{nmol} / \mathrm{l}(15.5(1.6)$ to $20.8(1.4) \mu \mathrm{g} / 100 \mathrm{ml})$ at 60 minutes (peaks, $\mathbf{p}<0.05$ ) (fig 3 ). Four subjects with normal cortisol reserve were given arginine vasopressin alone on separate occasions. Basal and peak cortisol values were $429(58)$ and $439(54) \mathrm{nmol} / \mathrm{l}(15 \cdot 5(2 \cdot 1)$ and $15 \cdot 9(2 \cdot 0)$ $\mu \mathrm{g} / 100 \mathrm{ml})$. Their mean peak cortisol concentration achieved in the releasing factor test without vasopressin $(780 \mathrm{nmol} / \mathrm{l} ; 28.3 \mu \mathrm{g} / 100 \mathrm{ml})$ was not significantly different from that achieved with the insulin combined test $(664 \mathrm{nmol} / \mathrm{l} ; 24 \cdot 1 \mu \mathrm{g} / 100 \mathrm{ml})$. The peak concentration of growth hormone in the releasing factor test with arginine vasopressin was $42 \cdot 4(11 \cdot 2) \mathrm{mU} / \mathrm{l}$ at 60 minutes and without arginine vasopressin $18.9(5 \cdot 7) \mathrm{mU} / \mathrm{l}$ at 30 minutes $(\mathrm{p}<0.001)$ (fig 4). There was no change in growth hormone concentration in the four subjects given vasopressin alone. The peak growth hormone concentration seen in the releasing factor test without vasopressin $(23.0$ $\mathrm{mU} / \mathrm{l})$ was not significantly different from that in the insulin combined test $(18 \cdot 7 \mathrm{mU} / \mathrm{l})$.

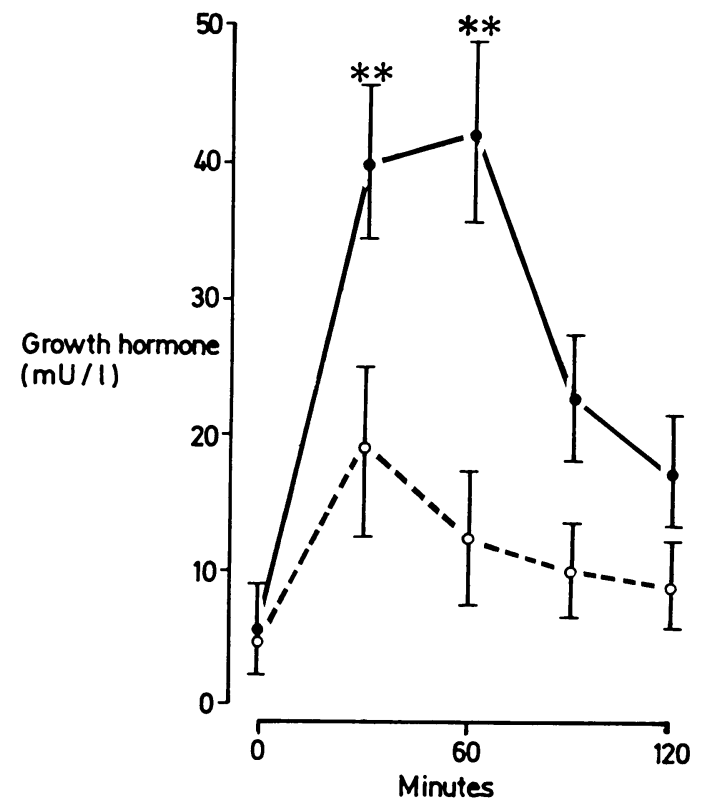

FIG 4-Comparison of serum growth hormone response to combined releasing factors with $(O)$ and without $(O)$ arginine vasopressin in eight subjects. Points are means. Bars are SEM. ${ }^{\star} \mathrm{p}<0.001$.

\section{Discussion}

The usefulness of a combined test to assess anterior pituitary reserve has been clearly shown, ${ }^{423}$ but those studies used insulin induced hypoglycaemia as the stimulus for the release of growth hormone and cortisol. Growth hormone releasing factor and corticotrophin releasing factor specifically stimulate growth hormone and cortisol release respectively, ${ }^{76}$ and in our study the four releasing factors given in combination with arginine vasopressin did not produce significantly different release of thyroid stimulating hormone, luteinising hormone, follicle stimulating hormone, and prolactin from that with the conventional combined test using insulin. In the case of prolactin it might be expected that the stress of insulin induced hypoglycaemia in the classical test would cause a 
greater response than the releasing factor test, but we did not find this. Nevertheless, both the cortisol and growth hormone responses were found to be significantly greater in both the group of normal subjects and the total group studied with the releasing factor test. This increased response appeared to result from the inclusion of arginine vasopressin, without vasopressin cortisol and growth hormone responses were similar to those seen with the insulin combined test. Although arginine vasopressin is well known to stimulate secretion of adrenocorticotrophic hormone and hence cortisol, its synergistic effect with secretion of growth hormone releasing factor in man has not been reported. Arginine vasopressin alone had no effect on growth hormone secretion, and more studies (that is, in animals and isolated tissues) are needed to explore the precise relation in this apparently pronounced synergistic action.

The insulin combined test assesses hypothalamic-pituitary reserve, while the releasing factor test measures the readily releasable pool of anterior pituitary hormones. Thus in some cases of tumours in the pituitary area where stalk or hypothalamic damage has occurred it would be expected that results of the releasing factor test would differ from those of the insulin combined test. Other forms of hypothalamic insufficiency-for example, after cranial irradiation-would also be expected to show a different response, and the releasing factor test in these circumstances would not assess the need for hormone replacement therapy. The releasing factor test, however, is a valid clinical test of pituitary disease alone, and absence of response has the same implication in these cases as the results of an insulin combined test. The releasing factor test appears to be particularly valuable in assessing the extent of damage to pituitary function after surgery for pituitary tumours and also the success of pituitary ablation used in the treatment of hormone dependent cancers. In practical terms it is often known that pituitary tumours or other pituitary diseases exist and what is needed is a test of pituitary function as such; the releasing factor test is eminently applicable in this setting. The current cost of the basic peptide components of this test is $£ 65$ and, when manpower is considered, it may therefore be cheaper overall than the insulin combined test when this new combined releasing factor test becomes available commercially.

In most subjects the peak growth hormone and cortisol responses reportedly occur within $30-60$ minutes with the combined releasing factors. ${ }^{18}$ Our study confirms this and suggests that pituitary function may be evaluated with a 60 minute test rather than the 120 minutes required with the insulin combined test. The growth hormone response to growth hormone releasing factor has been reported to vary within the same subject ${ }^{79}$ and further study of individuals' variation in their response to the releasing factor test would be of interest.

Arginine vasopressin in the low dose used in this study has not been reported to have side effects, ${ }^{20}$ and we observed no reactions in the subjects studied. It is worth noting that thyrotrophin releasing hormone, used in both tests, has rarely been recorded as associated with pituitary apoplexy. ${ }^{24}$

Two studies using multiple releasing hormones without arginine vasopressin have been reported in normal subjects. ${ }^{1825}$ Our study reports the combined use of the four releasing factors together with vasopressin as a powerful test of the readily releasable pool of pituitary hormones in both normal subjects and patients with pituitary disorders. The releasing factor test is quicker and more pleasant than the insulin combined test. It is more feasible for use on an office basis (for example, not risking unconsciousness and not $\underline{\underline{T}}$ needing a supervised meal as required after insulin induced $\underset{z}{\vec{z}}$ hypoglycaemia) and may well prove to be generally safer, reducing the level of professional attention required. This test of pituitary function therefore appears to be a very useful addition to the insulin $\widehat{\widehat{O}}$ combined test, and indeed in some circumstances may replace it. Further work is required to establish the particular indications for $\mathrm{D}$ its clinical use.

\section{LM is in receipt of a Hammersmith Special Health Authority grant.}

\section{References}

1 Greenwood FC, Landon J, Stamp TCB. The plasma sugar, free fatty acid, cortisol and growth hormone response to insulin. 1. In control subjects. 7 Clin Invest 1966;45:429-36.

2 Burgus R, Dunn TF, De Siderio D, Ward DW, Vale W, Gullemin R. Characterisation of ovine ô hypothalamic hypophysiotropic TSH-releasing factor (TRF). Nature 1970;226:321-5.

3 Matsuo H, Baba Y, Nair RMG, Arimura A, Schally AV. Structure of porcine LH- and FSHreleasing hormone. 1. The proposed amino acid sequence. Biochems Biophys Res Commun 1971:43:1334-9.

4 Harsoulis P, Marshall JC, Kuku SF, Burke CW, London DR, Fraser TR. Combined test for $\vec{\omega}$ assessment of anterior pituitary function. Br Med f 1973;iv:326-9.

5 Rivier J, Spiess J, Thorner $M$, Vale W. Characterisation of a growth hormone relasing factor from a pancreatic islet tumour. Nature 1982;300:276-9.

6 Vale W, Spiess J, Rivier C, Rivier J. Characterisation of a 41-residue ovine hypothalamic peptide that stimulates secretion of corticotrophin and B-endorphin. Science 1981;213:1394-7.

7 Thorner MO, Rivier J, Spiess J, et al. Human pancreatic growth hormone releasing factor of selectively stimulates growth hormone secretion in man. Lancet 1983;i:24-8.

8 Rosenthal SM, Shriock EA, Kaplan SL, Guillemin R, Grumbach MM. Synthetic human pancreatic growth hormone-releasing factor (hpGRF 1-44-NH2) stimulates growth hormone if secretion in normal man. 7 Clin Endocrinol Metab 1983;57:677-9.

9 Vance ML, Borges JLC, Kaufer DL, et al. Human pancreatic tumor growth hormone-releasing factor: dose-response relationships in normal man. $\mathcal{F}$ Clin Endocrinol Metab 1984;58:838-44.

10 Grossman A, Wass JAH, Sueiras-Diaz J, et al. Growth-hormone-releasing factor in growth hormone deficiency: demonstration of a hypothalamic defect in growth hormone release. Lancet $N$ 1983;ii:137-8.

11 Laron Z, Keret R, Bauman B, et al. Differential diagnosis between hypothalamic and pituitary $T$ hGH deficiency with the aid of synthetic GH-RH 1-44. Clin Endocrinol (Oxf) 1984;11:9-12.

12 Vale W, Vaughan J, Smith M, Yamamoto G, Rivier J, Rivier C. Effects of synthetic ovine corticotrophin releasing factor, glucocorticoids, catecholamines, neurohypophysial peptides and other substances on cultured corticotrophic cells. Endocrinology 1983;113:1121-31.

13 Rivier C, Brownstein M, Spiess J, Rivier J, Vale W. In vivo corticotrophin-releasing factorinduced secretion of adrenocorticotrophin, B-endorphin, and corticocosterone. Endocrinology 1982;110:272-8

14 Grossman A, Kruseman ACN, Perry L, et al. New hypothalamic hormone, corticotrophin releasing factor, specifically stimulates the release of adrenocorticotrophic hormone and cortisol in man. Lancet 1982;i:921-2.

15 Muller OA, Dorr HG, Hagen B, Stalla GR, Von Werder K. Corticotrophin releasing factor (CRF) stimulation test in normal controls and patients with disturbances of hypothalamic-pituitaryadrenal axis. Klin Wochenschr 1982;60:1485-91.

16 Orth DN, Jackson RV, DeCherney GH, et al. Effect of synthetic ovine corticotrophin-releasing factor: dose response of plasma adrenocorticotrophin and cortisol. F Clin Invest 1983;71:587-95. 17 DeBold CR, Sheldon WR, DeCherney GR, et al. Arginine vasopressin potentiates ACTH release by ovine corticotrophin-releasing factor. $\mathcal{I}$ Clin Invest 1984;73:533-58.

18 Sheldon WR Jr, DeBoid CR, Evans WS, et al. Rapid sequential intravenous administration of four hypothalamic releasing hormones as a combined anterior pituitary function test in normal subjects. F Clin Endocrinol Metab 1985;60:623-30.

19 Gillies GE, Linton EA, Lowry PJ. Corticotrophin releasing activity of the new CRF is potentiated several times by vasopressin. Nature 1982;299:355-7.

20 Lamberts SWJ, Verleun T, Oosterom R, De Jong F, Hackens WHL. Corticotrophin-releasingfactor (ovine) and vasopressin exert a synergistic effect of adrenocorticotrophin release in man. $\mathcal{F}$ Clin Endocrinol Metab 1984;58:298-303.

21 Kelly WF, Mashiter K, Doyle FH, Banks LH, Joplin GF. Treatment of prolactin-secreting pituitary tumours in young women by needle implantation of radioactive yttrium. $Q \mathcal{F}$ Med 1978;188:473-93.

22 Seth J, Brown LM. A simple RIA for plasma cortisol. Clin Chim Acta 1978;86: 109-20.

23 Mortimer CH, Besser GM, McNally AS, Tunbridge WMG, Gomez-Pan A, Hall R. Interaction between secretion of the gonadotrophins, prolactin, growth hormone, thyrotrophin and corticosteroids in man; the effects of LH/FSH-RH, TRH and hypoglycaemia alone and in combination. Clinical Endocrinol (Oxf) 1973;2:317-26.

24 Chapman AJ, Williams G, Hackley AD, London DR. Pituitary apoplexy after combined test of Oे anterior pituitary function. BrMed f 1985;291:26.

25 Holl R, Fink P, Hetzel WD. Combined pituitary stimulation test with releasing hormones. Acta Endocrinol 1985;108 (suppl 267):20.

(Accepted 2 December 1985) 